PRACE GEOGRAFICZNE

zeszyt 157, 2019, 109-120

doi: 10.4467/20833113PG.19.012.10628

Instytut Geografii i Gospodarki Przestrzennej UJ

Komisja Geograficzna, Polska Akademia Umiejętności

Wydawnictwo Uniwersytetu Jagiellońskiego

\title{
MOŻLIWOŚCI OCENY WARUNKÓW MEZOKLIMATYCZNYCH WINNIC W POLSCE NA PODSTAWIE SIECI STACJI IMGW-PIB
}

\author{
Oskar Sękowski
}

\section{Possibilities of the evaluation of mesoclimatic conditions of vineyards in Poland based on the IMGW-PIB station network}

Abstract: The current global warming causes changes in traditional zones of viticulture worldwide. Poland becomes a country where there are more and more vineyards. The purpose of this work was to characterize vineyards in Poland and indicate in which vineyards there is a possibility of a precise characterization of mesoclimate. A database on the viticulture in Poland created on the basis of information from the Internet. A map was also created, presenting the distribution of vineyards and meteorological stations of the IMGW-PIB. Polygons with a radius of $30 \mathrm{~km}$ were designated, constituting the locational criterion for the precise characterization of mesoclimate. A map was prepared to present vineyards' distribution and Poland's land relief. There are 397 Polish vineyards in the data base. Above $82 \%$ of them are located within a radius of $30 \mathrm{~km}$ from the nearest meteorological station and most of them (94\%) are located to 400 meters above sea level and in river valleys. A favourable location in terms of the exposure and inclination of the slope characterizes respectively $58 \%$ and $45 \%$ of vineyards.

Keywords: vineyards, vine, mesoclimate, IMGW-PIB stations, Poland

Zarys treści: Współczesne ocieplenie powoduje, że następują zmiany tradycyjnych obszarów uprawy winorośli na świecie. Polska staje się krajem, w którym z roku na rok powstaje coraz więcej winnic. Celem opracowania jest charakterystyka winnic w Polsce oraz wskazanie, dla których winnic możliwa jest dokładna charakterystyka warunków mezoklimatycznych. 
Na podstawie informacji zawartych w Internecie utworzono bazę danych o uprawach winorośli w Polsce. Wykonano mapę, na której przedstawiono rozmieszczenie winnic oraz stacji meteorologicznych w ramach sieci IMGW-PIB. Na mapie wyznaczono poligony o promieniu $30 \mathrm{~km}$, oznaczające kryterium lokalizacyjne dla dokładnego określenia warunków mezoklimatycznych. Została także wykonana mapa prezentująca rozmieszczenie winnic oraz ukształtowanie terenu Polski. W opracowaniu uwzględniono 397 polskich winnic. Ponad $82 \%$ z nich znajduje się w promieniu $30 \mathrm{~km}$ od najbliższej stacji meteorologicznej i większość (94\%) zlokalizowana jest na wysokości do 400 m n.p.m. oraz w dolinach rzek. Korzystna lokalizacja ze względu na ekspozycję stoku oraz nachylenie dotyczy odpowiednio $58 \%$ i $45 \%$ winnic.

Stowa kluczowe: winnice, winorośl, mezoklimat, stacje IMGW-PIB, Polska

\section{Wstęp}

Obecna uprawa winorośli na świecie mieści się w tzw. wąskiej niszy klimatycznej, która ograniczona jest izotermami średniej rocznej temperatury powietrza $10^{\circ} \mathrm{Ci} 20^{\circ} \mathrm{C}$ (Houghton i in. 2001). Postępujące globalne ocieplenie może przyczynić się do zmian w niektórych tradycyjnych regionach winiarskich (Kenny, Harrison 1992). Południowe obszary Europy mogą stać się zbyt ciepłe dla wytwarzania wysokojakościowych win. Z kolei produkcja win w północnej części kontynentu europejskiego, czyli w krajach, które nie są tradycyjnie związane z uprawą winorośli, może stać się ponownie opłacalna (Butterfield i in. 2000; Kenny, Harrison 1992; Malheiro i in. 2010; Hannah i in. 2013, Moriondo i in. 2013).

Konsekwencje zmian klimatu dla uprawy winorośli były rozpatrywane m.in. przez Jonesa i Davisa (2000), którzy wykazali, że podczas ostatnich dwóch dekad XX w. początek okresu rozwoju winorośli następował wcześniej, natomiast przerwy pomiędzy poszczególnymi fazami rozwoju winorośli uległy skróceniu. Podobne wyniki uzyskali Moriondo i in. (2011) dla Toskanii oraz Bonnefoy i in. (2013) dla Doliny Loary. Zdaniem naukowców wcześniejszy początek kolejnych faz rozwoju winorośli spowoduje zmiany jakości i ilości wina na całym świecie. Stwierdzono, że w ostatnich latach, np. w Australii, dojrzewanie winogron następuje wcześniej, co jest efektem globalnego ocieplenia (Webb i in. 2012). Zmiany klimatu są więc szansą dla krajów do tej pory niekojarzonych z uprawą winorośli. Zaistniała zatem potrzeba oszacowania możliwości uprawy winorośli w miejscach, które do tej pory nie były tradycyjnie związane z produkcją wina (Bardin-Camparotto i in. 2014). Określenie korzystnych warunków klimatycznych oraz meteorologicznych w danym roku, a także usprawnienie zarządzania winnicami jest możliwe poprzez analizę bieżących oraz przewidywanych wartości elementów meteorologicznych (Grifoni i in. 2006). Wpływ warunków makroklimatycznych jest istotny przy analizie odpowiedniego obszaru pod uprawę winorośli (Tonietto, Carbonneau 2004), dlatego wybór odpowiedniej lokalizacji dla winnicy jest determinowany przez 
odpowiednie warunki klimatyczne, a następnie uwzględniane są takie czynniki jak: gleba, rzeźba terenu oraz mezoklimat (Białobrzeska i in. 2010). Zatem zakładanie większej winnicy powinno być oparte na analizie danych ze stacji meteorologicznych, które są zlokalizowane możliwie najbliżej planowanej winnicy, w odległości nie większej niż $30 \mathrm{~km}$. Odległość ta oznacza możliwość dokładnej charakterystyki warunków mezoklimatycznych (Bosak 2006). Szczegółowa analiza warunków środowiska geograficznego w takich regionach jak np. Okanagan Valley (Kanada), Central Otago (Nowa Zelandia) przyczyniła się do tego, że produkowane w tych miejscach wina zajmują czołowe miejsca w konkursach międzynarodowych. Należy zauważyć, że pierwsze uprawy winorośli w tych miejscach powstały zaledwie 30 lat temu (Bosak 2004).

Uznaje się, że możliwość towarowej uprawy winorośli istnieje w miejscach, które spełniają podstawowe wymogi klimatyczne. Są one związane głównie z wymaganiami termicznymi, do których należą: średnia roczna temperatura powietrza około $8^{\circ} \mathrm{C}$, średnia temperatura powietrza w okresie wegetacyjnym $14^{\circ} \mathrm{C}$, średnia temperatura powietrza najcieplejszego miesiąca w roku $-17^{\circ} \mathrm{C}$ oraz suma temperatur aktywnych wynosząca około $2500^{\circ} \mathrm{C}$. Istotne są także warunki geograficzne - lokalizacja winnicy. Przyjmuje się, że winorośl w Polsce powinna być uprawiana do wysokości $400 \mathrm{~m}$ n.p.m., najlepiej na zboczach, gdzie dochodzi do szybkiego odpływu z terenu winnicy zimnych, ciężkich mas powietrza. $\mathrm{W}$ ten sposób w dnie doliny tworzy się zastoisko mrozowe, wypierając do góry ciepłe powietrze, które przyczynia się do ochrony winnicy przed przymrozkami. $\mathrm{W}$ dodatku powinny być to zbocza dobrze nasłonecznione, czyli najlepiej południowe i południowo-zachodnie, w następnej kolejności południowo-wschodnie wystawione na bezpośrednie działanie promieni słonecznych przez możliwie jak najdłuższą część dnia. Korzystna uprawa winorośli związana jest z dużą ilością promieniowania słonecznego, które powinno dopływać przez możliwie największą część dnia. Wiatr osiągający prędkość do 2-3 $\mathrm{m} \cdot \mathrm{s}^{-1}$ wpływa korzystnie na stan zdrowotny krzewów. Silniejsze podmuchy powodują ochłodzenie przygruntowej warstwy powietrza (Bosak 2004).

Celem opracowania jest charakterystyka winnic w Polsce oraz wskazanie, dla których winnic możliwa jest syntetyczna charakterystyka warunków mezoklimatycznych i meteorologicznych, na podstawie danych pochodzących z istniejącej sieci stacji IMGW-PIB. Niniejsze opracowanie jest wstępem do dalszych badań na temat uwarunkowań klimatycznych i meteorologicznych uprawy winorośli w Polsce w aspekcie współczesnego ocieplenia klimatu.

W polskiej literaturze klimatologicznej niewiele jest opracowań dotyczących oceny potencjału warunków klimatycznych do uprawy winorośli. Nie przeprowadzono także inwentaryzacji winnic znajdujących się na terenie kraju. Bokwa i Klimek (2009) dokonali analizy elementów klimatycznych ważnych dla uprawy winorośli na 
Pogórzu Wielickim. Lisek (2007) zajmował się oceną uszkodzeń mrozowych winorośli po zimie 2005/2006 w warunkach centralnej Polski. W innej publikacji ten sam autor (Lisek 2008) wyznaczył czynniki ograniczające rozwój winnic w centralnej Polsce. Bardzo ważna pod kątem możliwości uprawy winorośli w Polsce jest publikacja Białobrzeskiej i in. (2010), w której stwierdzono, że w naszym kraju istnieją obszary korzystne dla uprawy winorośli, nawet dla odmian późno dojrzewających. Badania Kryzy i in. (2015) potwierdziły, że następują korzystne zmiany w strukturze klimatu Polski pod kątem uprawy winorośli oraz zaznacza się spadek częstości występowania czynników zagrażających uprawie.

\section{Dane i metody}

Dane dotyczące winnic w Polsce zebrano na podstawie informacji zawartych na witrynach internetowych poszczególnych winnic oraz z serwisu internetowego winogrodnicy.pl. W opracowanej bazie danych uwzględniono: nazwę winnicy, współrzędne geograficzne w formacie dziesiętnym, stronę internetową, miejscowość, gminę, powiat oraz wysokość nad poziomem morza. Winnice zostały pogrupowane również pod kątem województw, w których są zlokalizowane. Poniżej przedstawiono przykładową tabelę (tab. 1) pochodzącą z inwentaryzacji winnic w Polsce.

Informacje dotyczące polskich stacji synoptycznych i klimatologicznych zostały pozyskane ze strony internetowej Instytutu Meteorologii i Gospodarki Wodnej Państwowy Instytut Badawczy (https://dane.imgw.pl/data/dane_pomiarowo_obserwacyjne/). Dodatkowym elementem opracowania było uwzględnienie typu każdej stacji. Baza danych wykorzystana w opracowaniu, dotycząca sieci stacji synoptycznych i klimatologicznych w Polsce, zawiera 67 obiektów (tab. 2). Analizując typ stacji, największą liczbę (41) stanowią stacje hydrologiczno-meteorologiczne (synoptyczne). $Z$ punktu widzenia badań istotne są także stacje klimatologiczne (5). Najwięcej stacji ulokowanych jest w granicach województwa pomorskiego (7), najmniej zaś w województwie opolskim (1) (ryc. 2). Dane obserwacyjno-pomiarowe dostępne są od 1951 r. dla stacji klimatologicznych oraz od 1960 r. dla stacji synoptycznych. Dane te są dostępne jako wartości terminowe, dobowe i miesięczne. Dla stacji klimatologicznych i synoptycznych dostępne są następujące dane dobowe istotne dla podjętego tematu: temperatura (maksymalna, minimalna, średnia), temperatura minimalna przy gruncie, suma opadów, rodzaj opadu, wysokość pokrywy śnieżnej, średnia wilgotność względna, średnia prędkość wiatru, średnie zachmurzenie. Z punktu widzenia przyszłych badań ważne będą także dane ze stacji opadowych, dla których dostępne są następujące wartości dobowe: suma opadów, rodzaj opadu, wysokość pokrywy śnieżnej, wysokość świeżo spadłego śniegu, rodzaj pokrywy śnieżnej, gatunek śniegu. 
Tab. 1. Przykładowa tabela inwentaryzacji winnic w Polsce (dane z 2018 r.)

Table 1. Exemplary table of vineyard inventarisation in Poland (data from 2018)

\begin{tabular}{|c|c|c|c|c|c|c|}
\hline \multicolumn{7}{|c|}{$\begin{array}{l}\text { Województwo dolnośląskie } \\
\text { Dolnośląskie Voivodeship }\end{array}$} \\
\hline $\begin{array}{l}\text { Nazwa } \\
\text { Name }\end{array}$ & $\begin{array}{l}\text { Współ. geogr. } \\
\text { Coordinates }\end{array}$ & $\begin{array}{l}\text { Strona internetowa } \\
\text { Website }\end{array}$ & $\begin{array}{l}\text { Miejscowość } \\
\text { Locality }\end{array}$ & $\begin{array}{l}\text { Gmina } \\
\text { Commune }\end{array}$ & $\begin{array}{l}\text { Powiat } \\
\text { County }\end{array}$ & $\begin{array}{l}\text { Wysokość } \\
\text { (m n.p.m.) } \\
\text { Altitude } \\
\text { (m a.s.l.) }\end{array}$ \\
\hline Adoria & $\begin{array}{l}50^{\circ} 58^{\prime} \mathrm{N} \\
16^{\circ} 46^{\prime} \mathrm{E}\end{array}$ & www.winnicaadoria.pl & Zachowice & $\begin{array}{c}\text { Kąty } \\
\text { Wrocławskie }\end{array}$ & wrocławski & 154 \\
\hline Agat & $\begin{array}{l}51^{\circ} 01^{\prime} \mathrm{N} \\
15^{\circ} 49^{\prime} \mathrm{E}\end{array}$ & www.winnicaagat.pl & Sokołowiec & Świerzawa & złotoryjski & 295 \\
\hline Alvarium & $\begin{array}{l}51^{\circ} 33^{\prime} \mathrm{N} \\
15^{\circ} 49^{\prime} \mathrm{E}\end{array}$ & www.facebook.com/winnicaalvarium & Ostaszów & Przemków & polkowicki & 133 \\
\hline Hanna & $\begin{array}{l}51^{\circ} 03^{\prime} \mathrm{N} \\
14^{\circ} 58^{\prime} \mathrm{E}\end{array}$ & www.winiarniahanna.pl & Radomierzyce & Zgorzelec & zgorzelecki & 196 \\
\hline Jadwiga & $\begin{array}{l}51^{\circ} 14^{\prime} \mathrm{N} \\
16^{\circ} 59^{\prime} \mathrm{E} \\
\end{array}$ & www.winnicajadwiga.pl & Ozorowice & $\begin{array}{c}\text { Wisznia } \\
\text { Mała }\end{array}$ & trzebnicki & 123 \\
\hline Jaksonowice & $\begin{array}{l}51^{\circ} 15^{\prime} \mathrm{N} \\
17^{\circ} 13^{\prime} \mathrm{E}\end{array}$ & rafal.wesolowski@wino.org.pl & Jaksonowice & Długołęka & wrocławski & 171 \\
\hline Jakubów & $\begin{array}{l}51^{\circ} 35^{\prime} \mathrm{N} \\
15^{\circ} 59^{\prime} \mathrm{E}\end{array}$ & www.winnicajakubow.pl & Radwanice & Radwanice & polkowicki & 198 \\
\hline Jaspis & $\begin{array}{l}51^{\circ} 05^{\prime} \mathrm{N} \\
15^{\circ} 41^{\prime} \mathrm{E}\end{array}$ & www.winnica-jaspis.eu & Dłużec & $\begin{array}{l}\text { Lwówek } \\
\text { Śląski }\end{array}$ & $\begin{array}{l}\text { Lwówek } \\
\text { Śląski }\end{array}$ & 242 \\
\hline Jaworek & $\begin{array}{l}51^{\circ} 11^{\prime} \mathrm{N} \\
16^{\circ} 44^{\prime} \mathrm{E}\end{array}$ & www.winnicejaworek.pl & Miękinia & Miękinia & średzki & 105 \\
\hline
\end{tabular}

Tab. 2. Lista stacji sieci IMGW-PIB wraz ze współrzędnymi

Table 2. Meteorological stations of the IMGW-PIB with coordinates

\begin{tabular}{|c|c|c|c|c|c|}
\hline $\begin{array}{c}\text { Lp. } \\
\text { No. }\end{array}$ & $\begin{array}{c}\text { Stacja } \\
\text { Station }\end{array}$ & $\begin{array}{c}\text { Typ } \\
\text { Type }\end{array}$ & $\begin{array}{c}\text { Szer. geogr. }{ }^{\circ} \mathrm{N} \\
\text { Latitude }{ }^{\prime} \mathrm{N}\end{array}$ & $\begin{array}{c}\text { Dł. geogr. }{ }^{\circ} \mathrm{E} \\
\text { Longitude }{ }^{\circ} \mathrm{E}\end{array}$ & $\begin{array}{c}\text { Województwo } \\
\text { Voivodeship }\end{array}$ \\
\hline 1 & Wrocław & M+LSM & $51^{\circ} 06^{\prime}$ & $16^{\circ} 53^{\prime}$ & dolnośląskie \\
\hline 2 & Jelenia Góra & SHM & $50^{\circ} 54^{\prime}$ & $15^{\circ} 48^{\prime}$ & dolnośląskie \\
\hline 3 & Śnieżka & WOM & $50^{\circ} 44^{\prime}$ & $15^{\circ} 44^{\prime}$ & dolnośląskie \\
\hline 4 & Kłodzko & SHM & $50^{\circ} 26^{\prime}$ & $16^{\circ} 37^{\prime}$ & dolnośląskie \\
\hline 5 & Bydgoszcz & LSM & $53^{\circ} 05^{\prime}$ & $17^{\circ} 59^{\prime}$ & kujawsko-pomorskie \\
\hline 6 & Toruń & SHM & $53^{\circ} 02^{\prime}$ & $18^{\circ} 35^{\prime}$ & kujawsko-pomorskie \\
\hline 7 & Terespol & SHM & $52^{\circ} 04^{\prime}$ & $23^{\circ} 37^{\prime}$ & lubelskie \\
\hline 8 & Lublin Radawiec & SHM & $51^{\circ} 13^{\prime}$ & $22^{\circ} 24^{\prime}$ & lubelskie \\
\hline 9 & Włodawa & SHM & $51^{\circ} 33^{\prime}$ & $23^{\circ} 32^{\prime}$ & lubelskie \\
\hline
\end{tabular}




\begin{tabular}{|c|c|c|c|c|c|}
\hline $\begin{array}{l}\text { Lp. } \\
\text { No. }\end{array}$ & $\begin{array}{l}\text { Stacja } \\
\text { Station }\end{array}$ & $\begin{array}{l}\text { Typ } \\
\text { Type }\end{array}$ & $\begin{array}{l}\text { Szer. geogr. }{ }^{\circ} \mathrm{N} \\
\text { Latitude }{ }^{\circ} \mathrm{N}\end{array}$ & $\begin{array}{l}\text { Dł. geogr. }{ }^{\circ} \mathrm{E} \\
\text { Longitude }{ }^{\circ} \mathrm{E}\end{array}$ & $\begin{array}{l}\text { Województwo } \\
\text { Voivodeship }\end{array}$ \\
\hline 10 & Zamość & ASS & $50^{\circ} 41^{\prime}$ & $23^{\circ} 12^{\prime}$ & lubelskie \\
\hline 11 & Jarczew & K & $51^{\circ} 49^{\prime}$ & $21^{\circ} 59^{\prime}$ & lubelskie \\
\hline 12 & Radzyń & $\mathrm{SH}$ & $51^{\circ} 52^{\prime}$ & $16^{\circ} 02^{\prime}$ & lubelskie \\
\hline 13 & Gorzów Wielkopolski & SHM & $52^{\circ} 45^{\prime}$ & $15^{\circ} 17^{\prime}$ & lubuskie \\
\hline 14 & Słubice & SHM & $52^{\circ} 21^{\prime}$ & $14^{\circ} 36^{\prime}$ & lubuskie \\
\hline 15 & Zielona Góra-Babimost & LSM+K & $52^{\circ} 08^{\prime}$ & $15^{\circ} 47^{\prime}$ & lubuskie \\
\hline 16 & Zielona Góra & SHM & $51^{\circ} 56^{\prime}$ & $15^{\circ} 32^{\prime}$ & lubuskie \\
\hline 17 & Wieluń & SHM & $51^{\circ} 13^{\prime}$ & $18^{\circ} 34^{\prime}$ & łódzkie \\
\hline 18 & Łódź & LSM & $51^{\circ} 44^{\prime}$ & $19^{\circ} 24^{\prime}$ & łódzkie \\
\hline 19 & Kraków-Balice & SHM+LSM & $50^{\circ} 04^{\prime}$ & $19^{\circ} 48^{\prime}$ & małopolskie \\
\hline 20 & Tarnów & ASS & $50^{\circ} 02^{\prime}$ & $20^{\circ} 59^{\prime}$ & małopolskie \\
\hline 21 & Zakopane & SHM & $49^{\circ} 18^{\prime}$ & $19^{\circ} 57^{\prime}$ & małopolskie \\
\hline 22 & Kasprowy Wierch & WOM & $49^{\circ} 14^{\prime}$ & $19^{\circ} 59^{\prime}$ & małopolskie \\
\hline 23 & Nowy Sącz & SHM & $49^{\circ} 37^{\prime}$ & $20^{\circ} 42^{\prime}$ & małopolskie \\
\hline 24 & Hala Gąsienicowa & K & $49^{\circ} 14^{\prime}$ & $20^{\circ} 00^{\prime}$ & małopolskie \\
\hline 25 & Muszyna & K & $49^{\circ} 21^{\prime}$ & $20^{\circ} 53^{\prime}$ & małopolskie \\
\hline 26 & Mława & SHM & $53^{\circ} 06^{\prime}$ & $20^{\circ} 21^{\prime}$ & mazowieckie \\
\hline 27 & Ostrołęka & ASS & $53^{\circ} 05^{\prime}$ & $21^{\circ} 34^{\prime}$ & mazowieckie \\
\hline 28 & Płock & ASS & $52^{\circ} 35^{\prime}$ & $19^{\circ} 44^{\prime}$ & mazowieckie \\
\hline 29 & Warszawa-Bielany & $\mathrm{K}$ & $52^{\circ} 17^{\prime}$ & $20^{\circ} 58^{\prime}$ & mazowieckie \\
\hline 30 & Siedlce & SHM & $52^{\circ} 11^{\prime}$ & $22^{\circ} 16^{\prime}$ & mazowieckie \\
\hline 31 & Kozienice & SHM & $51^{\circ} 34^{\prime}$ & $21^{\circ} 33^{\prime}$ & mazowieckie \\
\hline 32 & Opole & SHM & $50^{\circ} 37^{\prime}$ & $17^{\circ} 58^{\prime}$ & opolskie \\
\hline 33 & Rzeszów-Jasionka & SHM+LSM & $50^{\circ} 06^{\prime}$ & $22^{\circ} 03^{\prime}$ & podkarpackie \\
\hline 34 & Krosno & SHM & $49^{\circ} 42^{\prime}$ & $21^{\circ} 46^{\prime}$ & podkarpackie \\
\hline 35 & Lesko & SHM & $49^{\circ} 28^{\prime}$ & $22^{\circ} 20^{\prime}$ & podkarpackie \\
\hline 36 & Przemyśl & ASS & $49^{\circ} 48^{\prime}$ & $22^{\circ} 46^{\prime}$ & podkarpackie \\
\hline 37 & Suwałki & SHM & $54^{\circ} 08^{\prime}$ & $22^{\circ} 57^{\prime}$ & podlaskie \\
\hline 38 & Białystok & SHM & $53^{\circ} 06^{\prime}$ & $23^{\circ} 10^{\prime}$ & podlaskie \\
\hline 39 & Ustka & SHM & $54^{\circ} 35^{\prime}$ & $16^{\circ} 52^{\prime}$ & pomorskie \\
\hline 40 & Łeba & SHM & $54^{\circ} 45^{\prime}$ & $17^{\circ} 32^{\prime}$ & pomorskie \\
\hline 41 & Lębork & ASS & $54^{\circ} 33^{\prime}$ & $17^{\circ} 45^{\prime}$ & pomorskie \\
\hline
\end{tabular}


MoŻliwości oceny WARUnków MEZOKLIMATYCZNYCh WINNIC w POLSCE...

\begin{tabular}{|c|c|c|c|c|c|}
\hline $\begin{array}{l}\text { Lp. } \\
\text { No. }\end{array}$ & $\begin{array}{l}\text { Stacja } \\
\text { Station }\end{array}$ & $\begin{array}{l}\text { Typ } \\
\text { Type }\end{array}$ & $\begin{array}{l}\text { Szer. geogr. }{ }^{\circ} \mathrm{N} \\
\text { Latitude }{ }^{\circ} \mathrm{N}\end{array}$ & $\begin{array}{l}\text { Dł. geogr. }{ }^{\circ} \mathrm{E} \\
\text { Longitude }{ }^{\circ} \mathrm{E}\end{array}$ & $\begin{array}{l}\text { Województwo } \\
\text { Voivodeship }\end{array}$ \\
\hline 42 & Hel & SHM & $54^{\circ} 36^{\prime}$ & $18^{\circ} 49^{\prime}$ & pomorskie \\
\hline 43 & Gdańsk & LSM & $53^{\circ} 57^{\prime}$ & $18^{\circ} 52^{\prime}$ & pomorskie \\
\hline 44 & Gdańsk-Świbno & SHM & $54^{\circ} 20^{\prime}$ & $18^{\circ} 56^{\prime}$ & pomorskie \\
\hline 45 & Chojnice & SHM & $53^{\circ} 42^{\prime}$ & $17^{\circ} 33^{\prime}$ & pomorskie \\
\hline 46 & Racibórz & SHM & $50^{\circ} 03^{\prime}$ & $18^{\circ} 12^{\prime}$ & śląskie \\
\hline 47 & Częstochowa & ASS & $50^{\circ} 49^{\prime}$ & $19^{\circ} 06^{\prime}$ & śląskie \\
\hline 48 & Katowice-Pyrzowice & LSM & $50^{\circ} 29^{\prime}$ & $19^{\circ} 05^{\prime}$ & śląskie \\
\hline 49 & Katowice & SHM & $50^{\circ} 14^{\prime}$ & $19^{\circ} 02^{\prime}$ & śląskie \\
\hline 50 & Bielsko-Biała & SHM & $49^{\circ} 48^{\prime}$ & $19^{\circ} 00^{\prime}$ & śląskie \\
\hline 51 & Kielce-Suków & SHM & $50^{\circ} 48^{\prime}$ & $20^{\circ} 41^{\prime}$ & świętokrzyskie \\
\hline 52 & Sandomierz & ASS & $50^{\circ} 42^{\prime}$ & $21^{\circ} 43^{\prime}$ & świętokrzyskie \\
\hline 53 & Elbląg-Milejewo & SHM & $54^{\circ} 13^{\prime}$ & $19^{\circ} 32^{\prime}$ & warmińsko-mazurskie \\
\hline 54 & Kętrzyn & SHM, ASS & $54^{\circ} 04^{\prime}$ & $21^{\circ} 22^{\prime}$ & warmińsko-mazurskie \\
\hline 55 & Olsztyn & SHM & $53^{\circ} 46^{\prime}$ & $20^{\circ} 25^{\prime}$ & warmińsko-mazurskie \\
\hline 56 & Mikołajki & SHM & $53^{\circ} 47^{\prime}$ & $21^{\circ} 35^{\prime}$ & warmińsko-mazurskie \\
\hline 57 & Piła & SHM & $53^{\circ} 08^{\prime}$ & $16^{\circ} 45^{\prime}$ & wielkopolskie \\
\hline 58 & Koło & ASS & $52^{\circ} 12^{\prime}$ & $18^{\circ} 40^{\prime}$ & wielkopolskie \\
\hline 59 & Leszno-Strzyżewice & ASS & $51^{\circ} 50^{\prime}$ & $16^{\circ} 32^{\prime}$ & wielkopolskie \\
\hline 60 & Kalisz & SHM & $51^{\circ} 46^{\prime}$ & $18^{\circ} 04^{\prime}$ & wielkopolskie \\
\hline 61 & Kołobrzeg-Dźwirzyno & SHM & $54^{\circ} 11^{\prime}$ & $15^{\circ} 35^{\prime}$ & zachodniopomorskie \\
\hline 62 & Koszalin & SHM & $54^{\circ} 12^{\prime}$ & $16^{\circ} 09^{\prime}$ & zachodniopomorskie \\
\hline 63 & Świnoujście & SHM & $53^{\circ} 55^{\prime}$ & $14^{\circ} 14^{\prime}$ & zachodniopomorskie \\
\hline 64 & Szczecin & SHM & $53^{\circ} 24^{\prime}$ & $14^{\circ} 37^{\prime}$ & zachodniopomorskie \\
\hline 65 & Goleniów & LSM & $53^{\circ} 35^{\prime}$ & $14^{\circ} 54^{\prime}$ & zachodniopomorskie \\
\hline 66 & Resko-Smólsko & ASS & $53^{\circ} 46^{\prime}$ & $15^{\circ} 25^{\prime}$ & zachodniopomorskie \\
\hline 67 & Szczecinek & ASS & $53^{\circ} 42^{\prime}$ & $16^{\circ} 44^{\prime}$ & zachodniopomorskie \\
\hline
\end{tabular}

Objaśnienia: SHM - Stacja Hydrologiczno-Meteorologiczna (synoptyczna); LSM - Lotniskowa Stacja Meteorologiczna; WOM - Wysokogórskie Obserwatorium Meteorologiczne; K - Stacja Klimatologiczna; ASS - Automatyczna Stacja Synoptyczna.

Explanations: SHM - Hydro-Meteorological Station (synoptic); LSM - Airport Meteorological Station; WOM - Alpine Meteorological Observatory; K - Climatological Station; ASS - Automatic Synoptic Station. 
Bazy danych winnic oraz stacji meteorologicznych zostały stworzone ze względu na analizę ich wzajemnego położenia. W opracowaniu wykorzystano kryterium odległościowe wskazane przez Bosaka (2006) w celu dokładnej charakterystyki warunków mezoklimatycznych. W tym celu wyznaczono poligony - okręgi o promieniu $30 \mathrm{~km}$. Na podstawie modelu terenu określono ekspozycje oraz nachylenia stoków, na których zlokalizowane są winnice.

\section{Wyniki}

W Polsce zinwentaryzowano 397 winnic rozmieszczonych w poszczególnych województwach (ryc. 1). Winnice zlokalizowane są przede wszystkim w południowej oraz południowo-zachodniej części kraju. Najwięcej winnic przypada na województwo małopolskie (103), najmniej natomiast zlokalizowanych jest w województwie podlaskim oraz pomorskim (3).

Rozmieszczenie winnic w Polsce w powiązaniu z siecią stacji IMGW-PIB wskazuje, że $82 \%$ polskich gospodarstw winiarskich zlokalizowanych jest w promieniu $30 \mathrm{~km}$ od najbliższej stacji (ryc. 2). Należy zaznaczyć, iż w województwie pomorskim wszystkie

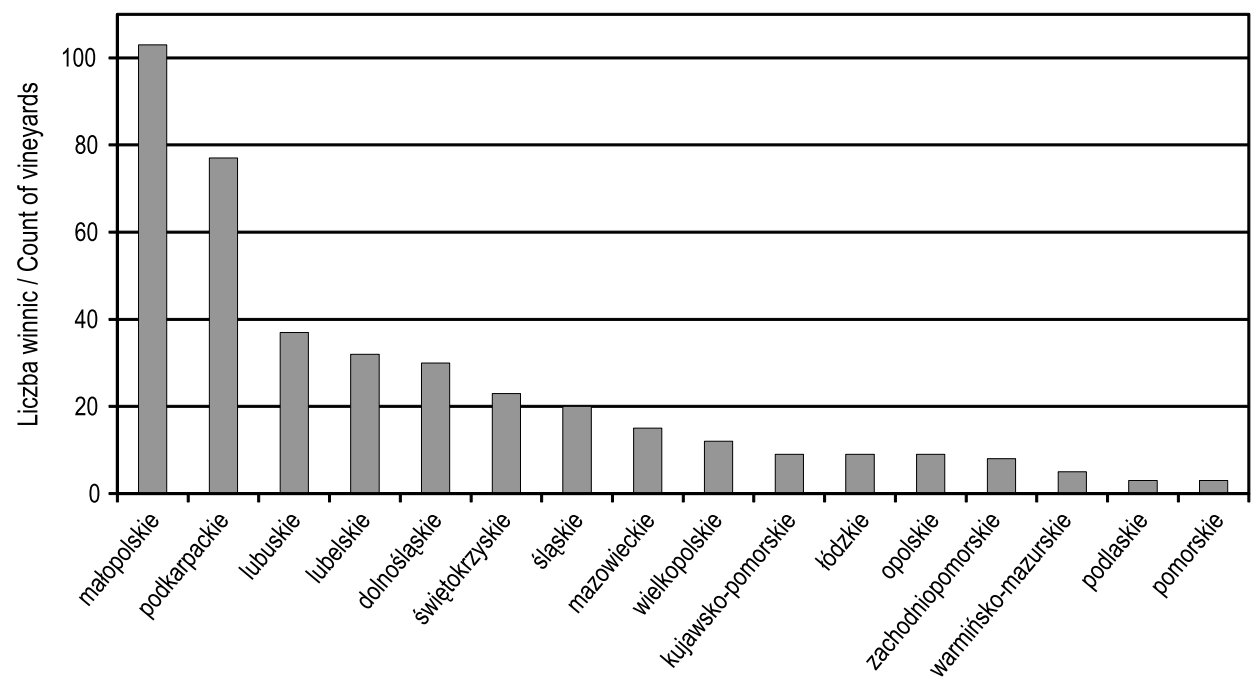

Województwa / Voivodeships

Ryc. 1. Liczba winnic w poszczególnych województwach w Polsce (dane dla 2018 r.)

Fig. 1. Number of vineyards in particular voivodeships in Poland (data from 2018) 


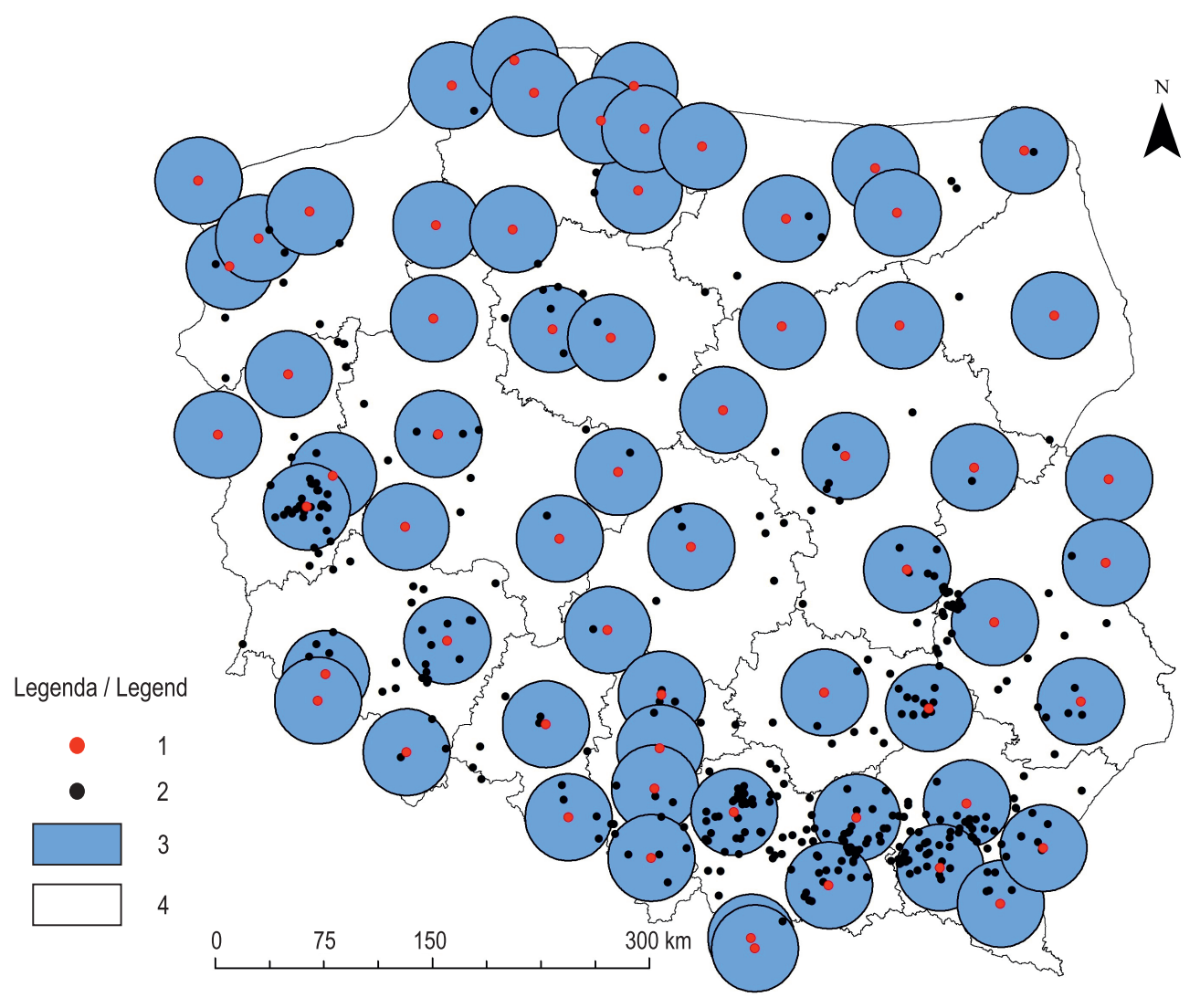

Ryc. 2. Wzajemne rozmieszczenie winnic oraz sieci stacji meteorologicznych w Polsce

Fig. 2. Mutual spatial distribution of vineyards and meteorological stations in Poland

Objaśnienia: 1 - stacje IMGW-PIB, 2 - winnice, 3 - zasięg stacji, 4 - granice województw.

Explanations: 1 - stations of IMGW-PIB, 2 - vineyards, 3 - a station's range, 4 - voivodeships' borders. 


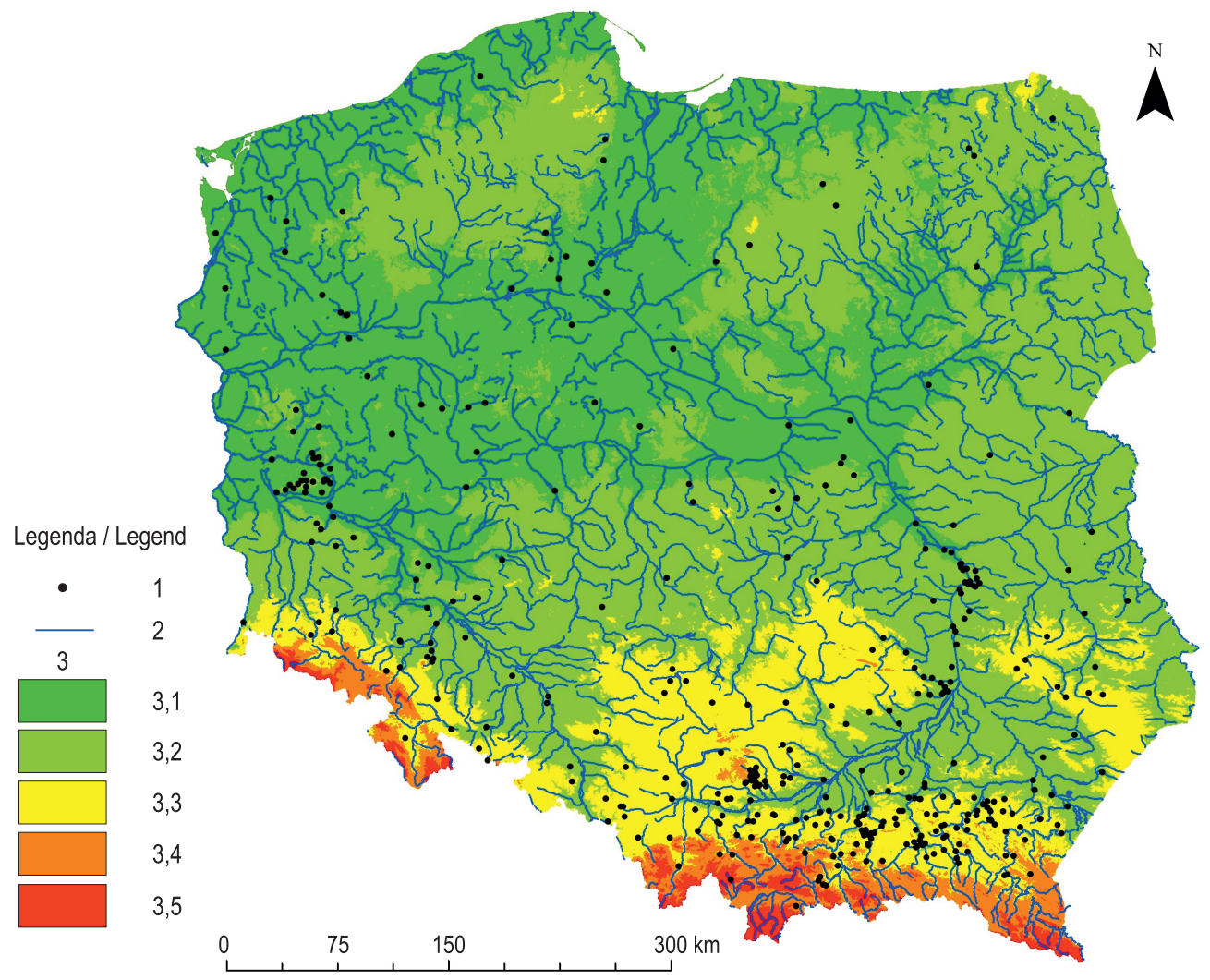

Ryc. 3. Lokalizacja winnic oraz ukształtowanie powierzchni w Polsce

Fig. 3. Location of vineyards and land relief in Poland

Objaśnienia: 1 - winnice; 2 - sieć rzeczna; 3 - wysokość n.p.m.; 3.1 - <118; 3.2 - 119-233; $3.3-234-424 ; 3.4-425-720 ; 3.5->721$.

Explanations: 1 - vineyards; 2 - rivers; 3 - altitude above sea level; 3.1 - <118; 3.2 - 119-233; $3.3-234-424 ; 3.4-425-720 ; 3.5->721$. 
winnice spełniają powyższe kryterium. Z kolei niewielka liczba stacji meteorologicznych w województwie małopolskim sprawia, że 17 winnic nie spełnia tego warunku.

Na podstawie analizy mapy ukształtowania terenu i rozmieszczenia winnic można stwierdzić, że lokalizacja istniejących winnic jest bardzo korzystna (ryc. 3). Na wysokości do 400 m n.p.m. położonych jest 375 obiektów winiarskich, co stanowi $94 \%$. Na obszarach nizinnych (do 230 m n.p.m) rozmieszczonych jest 213 winnic (56\%), w pasie wyżyn (do 420 m n.p.m) z kolei 183 winnice (46\%). Jedynie jedna winnica znajduje się na wysokości 722 m n.p.m. Najwięcej winnic (206) zlokalizowanych jest w pobliżu dużych rzek: Wisła, Wisłok, Wisłoka oraz Odra, co zapewnia korzystne dla uprawy winorośli warunki termiczno-wilgotnościowe.

$\mathrm{Na}$ stokach o korzystnym nasłonecznieniu (SW, S, SE, W) leży 58\% polskich winnic. Prawie połowa (46\%) zlokalizowana jest na stokach o nachyleniu 3-16 ${ }^{\circ}$. Zbiorcze zestawienie powyższych danych zaprezentowano w tabeli 3.

Tab. 3. Liczba oraz procent winnic w Polsce spełniających kryteria lokalizacyjne Table 3. Number and percentage of Polish vineyards fulfilling locational critera

\begin{tabular}{|c|c|c|c|}
\hline \multirow{2}{*}{$\begin{array}{l}\text { Kryterium } \\
\text { Criterion }\end{array}$} & \multirow{2}{*}{$\begin{array}{l}\text { Optymalne wartości } \\
\text { Optimal values }\end{array}$} & \multicolumn{2}{|c|}{$\begin{array}{l}\text { Spełnione } \\
\text { Fulfilled Full }\end{array}$} \\
\hline & & $\begin{array}{l}\text { Liczba } \\
\text { Number }\end{array}$ & $(\%)$ \\
\hline $\begin{array}{l}\text { Odległość od stacji } \\
\text { Distance to station }\end{array}$ & $30 \mathrm{~km}$ & 315 & 79 \\
\hline $\begin{array}{l}\text { Wysokość nad poziomem morza } \\
\text { Altitude above sea level }\end{array}$ & 300-400 m n.p.m. & 375 & 94 \\
\hline \multirow{4}{*}{$\begin{array}{l}\text { Ekspozycja } \\
\text { Exposure }\end{array}$} & SW & 53 & \multirow{4}{*}{58} \\
\hline & $S$ & 93 & \\
\hline & SE & 53 & \\
\hline & W & 33 & \\
\hline \multirow{2}{*}{$\begin{array}{l}\text { Nachylenie } \\
\text { Inclination }\end{array}$} & $3^{\circ}-5^{\circ}$ & 95 & 24 \\
\hline & $3^{\circ}-16^{\circ}$ & 181 & 46 \\
\hline $\begin{array}{c}\text { Obecność sieci rzecznej } \\
\text { Near to rivers }\end{array}$ & - & 206 & 52 \\
\hline
\end{tabular}

\section{Dyskusja i podsumowanie}

Przeważająca liczba winnic (94\%) położona jest na wysokości do $400 \mathrm{~m}$ n.p.m. Jest to zgodne z założeniami Myśliwca (2009), który zaznaczył, że w klimacie Polski winnice powinny być zakładane do wysokości około 300-400 m n.p.m. ze względu na to, 
że tereny położone wyżej, mimo dobrego nasłonecznienia, są chłodniejsze i o krótkim okresie wegetacji. Korzystne jest także położenie większości winnic na zboczu dolin oraz w dolinach rzek. Wyżej położone zbocza i wzgórza przyczyniają się do odpływu zimnej masy powietrza, co hamuje wiosenne przymrozki (Myśliwiec 2009). Wśród polskich winnic 181 (46\%) zlokalizowanych jest na stoku o nachyleniu w przedziale 3-16. Dla winnic zakładanych w Polsce najkorzystniejsze są stoki o ekspozycji południowej, południowo-zachodniej oraz południowo-wschodniej. Związane jest to z lepszym nasłonecznieniem wspomnianych stoków, co z kolei stwarza korzystniejsze warunki termiczne dla uprawy winorośli (Myśliwiec 2009). Na stokach o tychże ekspozycjach ulokowanych jest 199 winnic, co stanowi 51\%. Stoki zachodnie natomiast (33 winnice - 8\%) są korzystne ze względu na grubszą pokrywę śnieżną oraz okres jej zalegania - dłuższy niż w przypadku stoków o ekspozycji południowej. Stanowi to dodatkową ochronę przed ewentualnymi przymrozkami (Myśliwiec 2009).

Przedstawienie rozmieszczenia winnic w powiązaniu z siecią stacji meteorologicznych jest wstępem do analizy potencjału mezoklimatycznego dla uprawy winorośli w Polsce. Najwięcej winnic jest zlokalizowanych w województwach: małopolskim, dolnośląskim, lubuskim oraz podkarpackim. Sytuacja ta wynika przede wszystkim z uwarunkowań historycznych rozwoju winiarstwa w Polsce (Bosak 2004, 2006; Bokwa, Klimek 2009). Rozmieszczenie winnic we wspomnianych miejscach wynika również z korzystnych warunków klimatycznych, których dokładna analiza przyczyni się do syntetycznej oceny potencjału uprawy winorośli w Polsce. Większość winnic w Polsce (82\%) znajduje się w promieniu $30 \mathrm{~km}$ od najbliższej stacji IMGW-PIB, co stwarza szansę i możliwości określenia ich warunków mezoklimatycznych i stanowi pole dla syntetycznej charakterystyki warunków klimatycznych i meteorologicznych w danym roku. Dane klimatyczne uzupełnione o warunki lokalizacyjne winnic (ukształtowanie terenu, ekspozycja, nachylenie, gleby) stanowią bardzo dokładne i rzetelne źródło informacji na temat możliwości uprawy winorośli w danym miejscu. Przedstawiona mapa wzajemnego rozmieszczenia sieci stacji IMGW-PIB oraz winnic może stanowić również wskazówkę dla przyszłych winiarzy chcących wykorzystać odpowiednie warunki mezoklimatyczne i meteorologiczne potencjalnej winnicy.

\section{Literatura}

Bardin-Camparotto L., Blain G.C., Pedro M.J.J., Hernandes J.L., Cia P., 2014, Climate trends in a non-traditional high quality wine producing region, Bragantia Campinas, 733, 327-334.

Białobrzeska M., Kryza M., Szymanowski M., 2010, Thermal suitability of Poland forwine-growing in extreme years in comparision to other central European countries, Acta Agrophysica, 6, 34-45.

Bokwa A., Klimek M., 2009, Warunki klimatyczne Pogórza Wielickiego dla potrzeb uprawy winorośli [w:] A. Zborowski, Z. Górka (red.), Cstowiek i rolnictwo, Instytut Geografii i Gospodarki Przestrzeennej UJ, Krakó 103-111. 
Bonnefoy C., Quenol H., Bannardot V., Barbeau G., Madelin M., Planchon O., Neethling E., 2013, Temporal and spatial analyses of temperature in a French wine-producing area: the Loire Valley, International Journal of Climatology, 338, 1849-1862.

Bosak W., 2004, Uprawa winorosli i winiarstwo w matym gospodarstwie na Podkarpaciu, Polski Instytut Winorośli i Wina, Jasło.

Bosak W., 2006, Winorośl i wino w matym gospodarstwie w Matopolsce, Polski Instytut Winorośli i Wina, Kraków.

Butterfield R.E., Gawith M.J., Harrison P.A., Lonsdale K.J., Orr J., 2000, Modelling climate change impacts on wheat, potato and grapevine in Great Britain, [w:] T.E. Downing, P.A. Harrison, R.E. Butterfield, K.J. Lonsdale (red.), Climate change, climate variability and agriculture in Europe: an integrated assessment. Final report. Environmental Change Institute, University of Oxford.

Grifoni D., Mancini M., Maracchi G., Orlandini S., Zipoli G., 2006, Analysis of Italian wine quality using freely available meteorological information, American Journal of Enology and Viticulture, 573, 339-346.

Hannah L., Roehrdanz P.R., Ikegami M., Shepard A.V., Shaw M.R., Tabor G., Zhi L., Marquet P.A., Hijmans R.J., 2013, Climate change, wine and conservation, Proceedings of the National Academy of Sciences, 11017, 6907-6912.

Houghton J.T., Ding Y., Griggs D.J., Noguer M., Van der Linden PJ., Xiaosu D., 2001, Climate change 2001: the scientific basis. Contribution of working group I to the third assessment report of $I P C C$, Cambridge University Press, UK.

Jones G.V., Davis R.E., 2000, Climate influences on grapevine phenology, grape composition, and wine production and quality for Bordeaux, France, American Journal of Enology and Viticulture, 513, 249-261.

Kenny G.J., Harrison P.A., 1992, The effects of climate variability and change on grape suitability in Europe, Journal of Wine Research, 3, 163-183.

Kryza M., Szymanowski M., Błaś M., Migała K., Werner M., Sobik M., 2015, Observed changes in SAT and GDD and the climatological suitability of the Poland-Germany-Chech Republic transboundary region for wine grapes cultivation, Theoretical and Applied Climatology, 122, 207-2018.

Lisek J., 2007, Frost damage of grapevines in Poland following the winter of 2005/2006, Folia Horticulturae, 192, 69-78.

Lisek J., 2008, Climatic factors affecting development and yelding of grapevine in central Poland, Journal of Fruit and Ornamental Plant Research, 16, 285-293.

Malheiro A.C., Santos J.A., Fraga H., Pinto J.G., 2010, Climate change scenarios applied to viticultural zoning in Europe, Climate Research, 43, 163-177.

Moriondo M., Bindi M., Fagarazzi C., Ferrise R., Trombi G., 2011, Framework for high resolution climate change impact assessment on grapevines at a regional scale, Regional Environmental Change, 11, 553-567.

Moriondo M., Jones G.V., Bois B., Dibari C., Ferrise R., Trombi G., Bindi M.,2013, Projected shifts of wine regions in response to climate change, Climatic Change, 1193-4, 825-839. 
Myśliwiec R., 2009, Uprawa winorośli, Państwowe Wydawnictwo Rolnicze i Leśne, Kraków. Tonietto J., Carbonneau A., 2004, A multicriteria climatic classification system for grape-growing region worldwide, Agricultural and Forest Meteorology, 1-17.

Webb L., Whetton P.H., Bhend J., Darbyshire R., Briggs P.R., Barlow E.W.R., 2012, Earlier wine-grape ripening driven by climatic warming and drying and management practices, Nature Climate Change, 2(4), 259-264.

Oskar Sękowski

Uniwersytet Jagiellonski

Instytut Geografii i Gospodarki Præestrzennej

ul. Gronostajowa 7, 30-387 Kraków

oskar.sekowski@doctoral.uj.edu.pl 